\title{
Pengaruh Profitabilitas, Ukuran Perusahaan, Struktur Kepemilikan, Leverage, Dan Umur Perusahaan Pada Ketepatan Waktu Pelaporan Keuangan
}

\author{
I G A P Bunga Valentina ${ }^{1}$ \\ Gayatri $^{2}$ \\ ${ }^{1}$ Fakultas Ekonomi dan Bisnis Universitas Udayana (Unud), Bali, Indonesia \\ e-mail: bungavalentina88@gmail.com/Telp:+6289647329929 \\ ${ }^{2}$ Fakultas Ekonomi dan Bisnis Universitas Udayana (Unud), Bali, Indonesia
}

\begin{abstract}
ABSTRAK
Ketepatan waktu dalam penyajian laporan keuangan ke publik sangat dibutuhkan dan oleh karena itu tiap-tiap perusahaan diharapkan tidak melakukan penundaan dalam penyajian laporan keuangan. Salah satu cara untuk mengukur transparansi dan kualitas pelaporan keuangan adalah ketepatan waktu, rentang waktu antara tanggal laporan perusahaan dan tanggal ketika informasi keuangan diumumkan ke publik berhubungan dengan kualitas informasi keuangan yang dilaporkan. Ketepatwaktuan penyampaian laporan keuangan merupakan salah satu karakteristik penting dalam mendukung relevansi informasi keuangan. Informasi berpotensi kehilangan relevansinya karena usia dan perpanjangan waktu keterlambatan penyajian informasi laporan keuangan, sehingga menjadi informasi yang kurang berguna untuk pengambilan keputusan ekonomi.Tujuan penelitian ini adalah untuk menganalisis pengaruh profitabilitas, ukuran perusahaan, struktur kepemilikan, leverage, dan umur perusahaan terhadap ketepatan waktu pelaporan keuangan. Populasi penelitian adalah seluruh perusahaan bank yang terdaftar di BEI periode 2012-2016 yang seluruhnya berjumlah 43 perusahaan bank, dan sampel dalam penelitian yang memenuhi kriteria yang dipilih dalam penentuan sampel adalah 28 perusahaan dengan jumlah keseluruhan sampel selama periode 2012-2016 sebanyak 140 perusahaan. Teknik analisis dalam penelitian ini menggunakan regresi logistic Berdasarkan hasil analisis ditemukan bahwa profitabilitas dan leverage tidak berpengaruh pada ketepatan waktu pelaporan keuangan sedangkan ukuran perusahaan, struktur kepemilikan dan umur perusahaan berpengaruh positif pada ketepatan waktu pelaporan keuangan. Hal ini membuktikan bahwa profitabilitas, ukuran perusahaan, struktur kepemilikan, leverage dan umur perusahaan dapat mempengaruhi ketepatan waktu pelaporan keuangan.
\end{abstract}

Kata kunci: Profitabilitas, ukuran perusahaan, struktur kepemilikan, leverage, umur perusahaan dan ketepatan waktu pelaporan keuangan.

\begin{abstract}
Timeliness in the presentation of financial statements to the public is needed and therefore each company is expected not to postpone the presentation of financial statements. One way to measure transparency and quality of financial reporting is timeliness, time span between the date of the company report and the date when financial information is publicly disclosed relates to the quality of the financial information reported. Timely delivery of financial statements is one of the important characteristics in supporting the relevance of financial information. Information has the potential to lose its relevance due to age and extension of time delay in the presentation of financial statement information, thus becoming less useful information for economic decision
\end{abstract}


making. The purpose of this study is to analyze the effect of profitability, firm size, ownership structure, leverage, and firm age on timeliness of reporting Finance. The research population is all bank companies registered in BEI for the period of 2012-2016 which totals totaling 43 bank companies, and samples in the research that meet the criteria selected in the sample determination are 28 companies with the total sample during the period 2012-2016 as many as 140 companies. Analytical techniques in this study using logistic regression Based on the results of the analysis found that profitability and leverage does not affect the timeliness of financial reporting while firm size, ownership structure and age of the company have a positive effect on timeliness of financial reporting. This proves that profitability, firm size, ownership structure, leverage and age of the firm can affect the timeliness of financial reporting.

Keywords: Profitability, firm size, ownership structure, leverage, age of company and timeliness of financial reporting.

\section{PENDAHULUAN}

Industri perbankan telah mengalami perubahan besar dalam beberapa tahun terakhir dan di tahun 2015 perbankan termasuk dalam kategori sektor yang aktivitas keuangannya sangat kompleks. Bank sebagai salah satu lembaga keuangan di dalam perekonomian suatu negara, berfungsi sebagai penunjang kelancaran sistem pembayaran, pelaksanaan kebijakan moneter, dan sarana untuk mencapai stabilitas sistem keuangan yang menjalankan usahanya sehingga mempunyai kontribusi besar terhadap perkembangan bursa. Untuk itu diperlukan laporan keuangan sebagai bentuk pertanggung jawaban pihak manajemen perusahaan kepada pihak eksternal. Laporan keuangan merupakan suatu sarana dimana sebuah perusahaan dapat mengkomunikasikan informasi keuangannya kepada pihak luar dari perusahaan. Informasi ini digunakan untuk keperluan pengambilan keputusan, khususnya oleh beberapa pihak seperti investor, kreditur, pemerintah dan pihak-pihak yang berkepentingan (Arens et al, 2014). Informasi yang dihasilkan laporan keuangan akan sangat bermanfaat bagi pengguna laporan keuangan apabila informasi tersebut 
ISSN: 2302-8556

E-Jurnal Akuntansi Universitas Udayana

Vol.22.1. Januari (2018): 572-594

disajikan secara tepat waktu dan akurat. Salah satu cara untuk mengukur transparansi dan kualitas pelaporan keuangan adalah ketepatan waktu, rentang waktu antara tanggal laporan perusahaan dan tanggal ketika informasi keuangan diumumkan ke publik berhubungan dengan kualitas informasi keuangan yang dilaporkan (Mc Gee, 2007).

Ketepatwaktuan mengacu pada kualitas informasi yang tersedia pada waktu yang tepat atau informasi yang tepat waktu (Bonson dan Borrero, 2011). Ketepatan waktu pelaporan keuangan dengan jelas telah diatur dalam Keputusan Ketua Badan Pengawas Pasar Modal Nomor: 431/BL/2012 tentang kewajiban penyampaian laporan keuangan berkala. Dalam peraturan disebutkan bahwa penyampaian laporan keuangan selambat-lambatnya pada akhir bulan ke-empat (120 hari) setelah tanggal laporan keuangan tahunan. Perusahaan yang terlambat menyampaikan laporan keuangannya akan dikenakan sanksi administrasi dan denda sesuai dengan ketentuan yang ditetapkan oleh Bapepam dan LK. Adapun kasus-kasus pelanggaran ketepatan waktu terhadap aturan yang telah diterbitkan oleh Bapepam, yaitu Otoritas Jasa Keuangan (OJK) telah mencatat ada sebanyak 33 kasus pelanggaran di pasar modal pada tahun 2013. Pada tahun 2014 selanjutnya, berdasarkan catatan Bursa batas waktu penyampaian laporan keuangan interim periode 30 Juni 2014, dimana tanggal 4 Agustus 2014 laporan tersebut telah ditelaah secara terbatas atau yang diaudit oleh akuntan publik. Hasilnya sebanyak 23 emiten terlambat menyampaikan laporan keuangan interim yang berakhir per 30 Juni 2014. Pada periode 31 Desember 2015, 
perdagangan saham 18 perusahaan tercatat karena belum menyampaikan laporan keuangan (www.idx.go.id). Undang-undang No.8 tahun 1995 menyatakan apabila perusahaan terlambat dalam menyampaikan laporan keuangannya maka akan diberikan sanksi administrasi dan denda yang sesuai dengan ketentuan dalam undang-undang. Pemberikan sanksi dan denda terhadap perusahaan yang terlambat dalam penyampaian laporan keuangan melebihi batas waktu yang telah ditetapkan oleh bursa dimaksudkan agar para investor dapat lebih cepat mendapatkan informasi keuangan yang dibutuhkan sebagai pengambilan keputusan investasi.

Banyak penelitian yang telah dilakukan untuk menganalisis faktor-faktor penyebab perusahaan terlambat dalam menyampaikan laporan keuangannya. Bukti empiris yang ditemukan oleh peneliti-peneliti terdahulu menyebutkan bahwa keterlambatan laporan keuangan dikarenakan berita buruk perusahaan, seperti keterlambatan pelaporan keuangan dihubungkan dengan kesulitan keuangan, qualified opinion oleh auditor dan keterlambatan audit. Faktor lain yang sering ditemukan sebagai penentu ketepatan waktu pelaporan keuangan dalam perusahaan antara lain profitabilitas, ukuran perusahaan, leverage, umur perusahaan dan struktur kepemilikan. Profitabilitas, ukuran perusahaan dan umur perusahaan tidak berpengaruh terhadap ketepatan waktu pelaporan keuangan (Syahresy, 2015). Profitabilitas, ukuran perusahaan dan umur perusahaan berpengaruh positif terhadap ketepatan waktu pelaporan keuangan sedangkan struktur kepemilikan tidak berpengaruh terhadap ketepatan waktu pelaporan keuangan pada perusahaan yang 
ISSN: 2302-8556

E-Jurnal Akuntansi Universitas Udayana

Vol.22.1. Januari (2018): 572-594

terdaftar di BEI (Beladina, 2015). Penelitian mengenai faktor-faktor yang mempengaruhi ketepatan waktu pelaporan keuangan yang menggunakan faktor leverage keuangan suatu perusahaan dapat menggunakan debt to equity ratio (DER) menyatakan DER berpengaruh signifikan terhadap ketepatan waktu pelaporan keuangan (Marta, 2015). Sedangkan penelitian lain dengan variabel leverage menyatakan bahwa DER tidak berpengaruh terhadap ketepatan waktu pelaporan keuangan (Budiyanto dan Elma, 2015). Berdasarkan uraian diatas terdapat perbedaan hasil penelitian pada beberapa untuk variabel yang sama. Maka dari itu, penelitian semacam ini masih dibutuhkan untuk menjawab berbagai masalah yang berkaitan dengan faktor-faktor yang mempengaruhi ketepatan waktu pelaporan keuangan perusahaan perbankan yang terdaftar di Bursa Efek Indonesia.

Profitabilitas merupakan salah satu indikator keberhasilan perusahaan untuk dapat menghasilkan laba sehingga semakin tinggi profitabilitas maka semakin tinggi kemampuan perusahaan untuk menghasilkan laba bagi perusahaannya. Hasil penelitian Kholisah (2013) dan Marathani (2013) menunjukkan bahwa profitabilitas berpengaruh signifikan terhadap ketepatan waktu penyampaian laporan keuangan. Hasil ini menunjukkan bahwa jika suatu perusahaan dengan profitabilitas tinggi dimana merupakan suatu sinyal yang bagus, maka hal ini menjadi berita baik dan perusahaan cenderung untuk menyampaikan laporan keuangannya secara tepat waktu kepada pihak-pihak yang berkepentingan. Pihak manajemen perusahaan lebih mengetahui informasi mengenai internal perusahaan dan prospek perusahaan dimasa 
depan. Pihak manajemen harus memberikan informasi atau sinyal kepada para stakeholder baik sinyal baik atau sinyal buruk. Berdasarkan penjelasan penelitian terdahulu dan argumen di atas, maka dapat dirumuskan hipotesis penelitian ini sebagai berikut:

$\mathrm{H}_{1}$ : Profitabilitas berpengaruh positif pada ketepatan waktu pelaporan keuangan

Salah satu atribut yang dapat dihubungkan dengan ketepatan waktu penyampaian laporan keuangan adalah ukuran perusahaan. Perusahaan yang memiliki total asset yang lebih besar akan menyelesaikan audit lebih cepat dibandingkan dengan perusahaan yang memiliki total aset lebih kecil, hal ini dikarenakan perusahaan besar memiliki lebih banyak sumber daya, staf akuntansi, dan sistem informasi yang canggih. Menurut Beladina (2015) dan Marta (2015) menemukan bahwa ukuran perusahaan berpengaruh terhadap ketepatan waktu pelaporan keuangan, yakni perusahaan besar memiliki sumber daya yang besar, sehingga perusahaan perlu dan mampu dalam membiayai penyediaan informasi untuk keperluan pengungkapan kepada pihak eksternal perusahaan. Sebaliknya, perusahaan kecil memiliki sumber daya yang relatif sedikit, sehingga perusahaan memungkinkan tidak memiliki informasi yang siap untuk disajikan sebagaimana yang dimiliki oleh perusahaan besar, sehingga perusahaan kecil memiliki biaya tambahan yang relatif besar dalam melakukan pengungkapan informasi yang lebih lengkap.

$\mathrm{H}_{2}$ : Ukuran perusahaan berpengaruh positif pada ketepatan waktu pelaporan keuangan 
ISSN: 2302-8556

E-Jurnal Akuntansi Universitas Udayana

Vol.22.1. Januari (2018): 572-594

Struktur kepemilikan pada perusahaan didasarkan pada kepemilikan saham perusahaan. Kepemilikan saham dalam perusahaan dibagi menjadi dua aspek, yaitu kepemilikan pihak dalam dan kepemilikan pihak luar. Menurut Perdana Tulus (2014) dan Marta (2015) mengemukakan bahwa struktur kepemilikan saham publik berpengaruh signifikan terhadap ketepatan waktu pelaporan keuangan artinya struktur kepemilikan dari pihak luar mempunyai kekuatan yang besar untuk menekan manajemen agar menyajikan informasi secara tepat waktu dan perusahaan dengan proporsi kepemilikan publik yang besar cenderung tepat waktu dalam pelaporan keuangan.

$\mathrm{H}_{3}$ : Struktur kepemilikan berpengaruh positif pada ketepatan waktu pelaporan keuangan

Menurut Weston dan Copeland (1995) menyatakan bahwa rasio leverage mengukur tingkat aktiva perusahaan yang dibiayai oleh penggunaan hutang. Perusahaan yang mempunyai leverage yang tinggi berarti sangat tergantung pada pinjaman luar untuk membiayai aktivanya. Sedangkan perusahaan yang mempunyai leverage yang rendah lebih banyak membiayai investasinya dengan modal sendiri. Mengukur tingkat leverage keuangan suatu perusahaan dapat menggunakan debt to equity ratio (DER). DER berpengaruh terhadap ketepatan waktu pelaporan keuangan, oleh karena itu dapat disimpulkan bahwa perusahaan yang memiliki nilai DER rendah menunjukkan perusahaan tersebut memiliki hutang yang lebih kecil dari modal yang dimiliki, sehinga perusahaan akan lebih tepat waktu dalam menyampaikan pelaporan 
keuangan (Marta, 2015). Berdasarkan penelitan diatas maka, hipotesis yang diajukan adalah:

$\mathrm{H}_{4}$ : Leverage berpengaruh negatif pada ketepatan waktu pelaporan keuangan

Umur perusahaan menunjukan kredibilitas maupun reputasi perusahaan dimata masyarakat. Jika perusahaan telah lama berdiri biasanya dianggap memiliki kinerja yang baik sehingga menimbulkan kepercayaan masyarakat. Perusahaan yang telah lama berdiri, secara langsung membuktikan bahwa perusahaan mampu bertahan dan meraih laba dalam berbagai kondisi ekonomi. Perusahaan yang mempunyai umur yang relatif lebih, biasanya lebih baik mengumpulkan, memproses dan menghasilkan informasi, hal itu dikarenakan perusahaan sudah memiliki jam kerja yang banyak. Sedangkan perusahaan yang lebih muda lebih rentan terhadap kegagalan karena kurangnya pengalaman (Iyoha, 2012).

$\mathrm{H}_{5}$ : Umur perusahaan berpengaruh positif pada ketepatan waktu pelaporan keuangan

\section{METODE PENELITIAN}

Penelitian ini adalah penelitian dengan menggunakan pendekatan kuantitatif dan bentuk penelitian kausal, yaitu penelitian terhadap data yang dikumpulkan setelah terjadi suatu fakta atau peristiwa. Karakteristik masalah dari penelitian ini berupa hubungan sebab akibat antara dua variabel atau lebih. Adapun tujuan dari penelitian ini adalah untuk mengetahui pengaruh profitabilitas, ukuran perusahaan, struktur kepemilikan, leverage dan umur perusahaan pada ketepatan waktu pelaporan keuangan. Penelitian ini dilakukan pada Bursa Efek Indonesia (BEI) melalui website 
ISSN: 2302-8556

E-Jurnal Akuntansi Universitas Udayana

Vol.22.1. Januari (2018): 572-594

www.idx.co.id dengan mengunduh laporan keuangan auditan perusahaan perbankan sebagai data di tahun 2012-2016 terkait pengaruh profitabilitas, ukuran perusahaan dan struktur kepemilikan terhadap ketepatan waktu pelaporan keuangan. Objek penelitian ini adalah ketepatan waktu pelaporan keuangan, studi pada perusahaan perbankan yang terdaftar di Bursa Efek Indonesia (BEI) tahun 2012-2016.

Variable terikat atau dependen variable merupakan variabel yang dipengaruhi atau menjadi akibat karena adanya variabel-variabel bebas (Sugiyono, 2009). Variabel terikat dalam penelitian ini adalah ketepatan waktu pelaporan keuangan. Ketepatan waktu penyampaian laporan keuangan (timeliness) diukur berdasarkan tanggal penyampaian laporan keuangan tahunan auditan ke Badan Pengawas Pasar Modal dan Lembaga Keuangan (Bapepam-LK). Skala data diukur dengan menggunakan variabel dummy dengan kategori untuk perusahaan yang terlambat/ tidak tepat waktu (menyampaiakan laporan keuangannya lebih dari 120 hari setelah tanggal laporan keuangan tahunan atau setelah tanggal 30 April) masuk kategori 1 dan untuk perusahaan yang memiliki ketepatan waktu (menyampaikan laporan keuangannya kurang dari 120 hari setelah tanggal laporan keuangan tahunan atau sebelum tanggal 30 April) masuk kategori 0.

Variabel bebas atau independen variable merupakan variabel yang mempengaruhi atau menjadi sebab perubahannya atau timbulnya variabel terikat (Sugiyono, 2010). Variabel bebas dalam penelitian ini adalah: profitabilitas, ukuran perusahaan, struktur kepemilikan, leverage, dan umur perusahaan. Secara teoritis, 
perusahaan yang memiliki profitabilitas tinggi relatif memiliki keleluasaan untuk mengelola laba dibanding perusahaan yang memiliki profitabilitas rendah (Wirda, 2007:27). Profitabilitas diukur dengan menggunakan Return On Asset (ROA). ROA merupakan indikator keberhasilan perusahaan (efektifitas manajemen) dalam menghasilkan profit. Semakin tinggi profit yang dihasilkan maka semakin tinggi pula tingkat efektifitas manajemen perusahaan tersebut. Perusahaan yang mengalami ROA tinggi memerlukan waktu untuk menyelesaikan audit lebih pendek dibandingkan dengan perusahaan yang mengalami profitabilitas rendah. Ukuran perusahaan adalah suatu skala dimana dapat diklasifikasikan besar kecil perusahaan dengan melihat total aset perusahaan. Pada penelitian ini, ukuran perusahaan diproksikan dengan menggunakan Ln total asset. ). Dengan menggunakan Natural Log, nilai tersebut dapat disederhanakan tanpa mengubah proporsi nilai asal yang sebenarnya. dengan menggunakan natural log nilai tersebut disederhanakan tanpa mengubah proporsi dari nilai asal yang sebenarnya, sehingga ukuran perusahaan dapat dirumuskan sebagai berikut (Kholisah, 2013). Struktur kepemilikan adalah presentase kepemilikan saham terbesar oleh pihak luar yang diukur dari berapa besar saham yang dimiliki oleh pihak luar pada perusahaan go public yang terdaftar di BEI (Kartikasari dan Luluk 2010). Leverage menggambarkan kemampuan perusahaan dengan modal sendiri untuk menjamin jumlah hutang yang dimiliki dan menunjukan proporsi pembelanjaan perusahaan yang dibiayai oleh pemegang saham (modal sendiri) dan dibiayai dari pinjaman. Menurut Jusia dan Dewi (2013) Debt to equity 
ISSN: 2302-8556

E-Jurnal Akuntansi Universitas Udayana

Vol.22.1. Januari (2018): 572-594

ratio merupakan rasio yang menunjukkan perbandingan antara jumlah hutang dengan jumlah modal perusahaan. Debt to Equity Ratio (DER) dihitung dengan membandingkan total hutang dengan total modal. Perusahaan yang telah lama berdiri umumnya memiliki profitabilitas yang lebih stabil dibandingkan perusahaan yang baru berdiri atau yang masih memiliki umur yang singkat. Perusahaan yang telah lama berdiri akan meningkatkan labanya karena adanya pengalaman dari manajemen sebelumnya dalam mengelola bisnisnya.Umur perusahaan dalam penelitian ini menggunakan tanggal listed-nya perusahaan di BEI (Syahresy, 2015).

Data kuantitatif adalah data dalam bentuk angka yang dapat dinyatakan dan diukur dengan satuan hitung atau data kuantitatif yang diangkakan (Sugiyono, 2014:14), dimana dalam penelitian ini berupa tanggal laporan keuangan auditan yang telah dipublikasikan yang terdaftar di Bursa Efek Indonesia tahun 2012-2016. Data kualitatif adalah data yang dapat dinyatakan dalam bentuk kata, kalimat, skema, dan gambar (Sugiyono, 2014:14), dimana dalam penelitian ini yaitu nama-nama perusahaan perbankan yang terdaftar di BEI tahun 2012-2016. Penelitian ini menggunakan data sekunder yang bersumber dari laporan keuangan auditan perusahaan perbankan yang terdaftar di Bursa Efek Indonesia (BEI) tahun 2012-2016 melalui website www.idx.co.id.

Populasi penelitian ini adalah seluruh perusahaan perbankan yang terdaftar di BEI pada tahun 2012-2016. Proses penentuan sampel menggunakan metode purposive sampling, yaitu metode penelitian sampel dengan pertimbangan tertentu, 
dimana anggota-anggota sampel akan dipilih sedemikian rupa sehingga sampel yang dibentuk tersebut akan dapat mewakili sifat-sifat poulasi (Sugiyono, 2010).

Metode pengumpulan data dalam penelitian ini adalah metode observasi non partisipan, dimana peneliti tidak ikut terlibat secara langsung dan hanya sebagai pengamat independen (Sugiyono, 2014: 204). Data yang diamati dalam penelitian ini yaitu annual report dan laporan keuangan auditan yang bersumber dari situs resmi Bursa Efek Indonesia (www.idx.co.id). Metode analisis data dalam penelitian ini menggunakan analisis regresi logistik. Metode ini digunakan karena variabel dependennya bersifat kategorikan (nominal) dan variabel independennya kombinasi antara metrik dan non metrik. Regresi logistik digunakan untuk menguji apakah variabel-variabel profitabilias, ukuran perusahaan, struktur kepemilikan, leverage dan umur perusahaan mempengaruhi ketepatan waktu pelaporan keuangan perusahaan (Imam Ghozali,2011).

$$
\ln \frac{T L}{1-T L}=\mathrm{ROA}+\mathrm{ASSET}+\mathrm{OWN}+\mathrm{DER}+\mathrm{AGE}+\mathrm{e} \ldots \ldots .(1)
$$

Keterangan :

$\begin{array}{ll}\ln \frac{T L}{1-T L} & =\text { Ketepatan waktu pelaporan keuangan } \\ \alpha & =\text { konstanta } \\ \text { ROA } & =\text { Profitabilitas ( Return On Asset) } \\ \text { ASSET } & =\text { Ukuran Perusahaan } \\ \text { OWN } & =\text { Struktur kepemilikan } \\ \text { DER } & =\text { leverage (Debt to Equity) } \\ \text { AGE } & =\text { Umur Perusahaan } \\ \mathrm{e} & =\text { error }\end{array}$

\section{HASIL PEMBAHASAN}


ISSN: 2302-8556

E-Jurnal Akuntansi Universitas Udayana

Vol.22.1. Januari (2018): 572-594

Analisis data dengan statistik deskripif memberikan penjelasan mengenai nilai minimum, maksimum, rata-rata dan standar deviasi dari masing-masing variabel.

Tabel 1. Statistik Deskriptif

\begin{tabular}{lrrrrr}
\hline & & & & & \\
& N & Minimum & Maximum & $\begin{array}{c}\text { Std. } \\
\text { Deviation }\end{array}$ \\
\hline Y & 28 & 0 & 1 & 0,5 & 0,509 \\
ROA & 28 & $-0,04$ & 0,05 & 0,013 & 0,019 \\
SIZE & 28 & 8,16 & 11,92 & 10,155 & 1,089 \\
STRUKTUR & & & & & \\
LAVERAGE & 28 & 0,61 & 1 & 0,978 & 0,076 \\
AGE & 28 & 0,35 & 1,16 & 0,726 & 0,209 \\
$\begin{array}{l}\text { Valid N } \\
\text { (listwise) }\end{array}$ & 28 & 4 & 35 & 16,036 & 7,72 \\
\hline Sumber: Data sekunder yang diolah, 2017 & & & \\
\hline
\end{tabular}

Statistik deskriptif pada tabel 4.2 menunjukkan bahwa nilai minimum unruk profitabilitas adalah -0,040, sedangkan nilai maksimum sebesar 0,050 Nilai tersebut menunjukkan bahwa tingkat profitabilitas yang diperoleh perusahaan antara -0,04\% sampai $0,05 \%$. Nilai rata-rata sebesar 0,013 dengan standar deviasi 0,019 hal ini menunjukkan bahwa rata-rata perusahaan sampel menghasilkan laba bersih sebesar $1,91 \%$.

Nilai minimum untuk ukuran perusahaan sebesar 8,160, sedangkan nilai maksimum sebesar 11,920. Hal ini menunjukkan bahwa tingkat ukuran perusahaan yang dimiliki oleh perusahaan sampel antara Rp.8,16 miliar sampai Rp.11,920 miliar. Nilai rata-rata ukuran perusahaan sebesar Rp.10,155 miliar dengan standar deviasi 
1,089. Nilai minimum untuk struktur kepemilikan sebesar 0,610 sedangkan nilai maksimum sebesar 1,000 Hal ini menunjukkan bahwa tingkat struktur kepemilikan yang dimiliki oleh perusahaan sampel antara $0,61 \%$ sampai $1 \%$. Nilai rata-rata struktur kepemilikan sebesar 0,978\% dengan standar deviasi 0,076.

Nilai minimum untuk leverage sebesar 0,350 sedangkan nilai maksimum sebesar 1,160. Hal ini menunjukkan bahwa tingkat leverage yang dimiliki perusahaan sampel antara $0,35 \%$ sampai $1,16 \%$. Nilai rata-rata leverage sebesar $0,726 \%$ rupiah dengan standar deviasi sebesar 0,209. Nilai minimum untuk umur perusahaan sebesar 4,00 sedangkan nilai maksimum sebesar 35,00. Hal ini menunjukkan bahwa tingkat umur perusahaan yang dimiliki perusahaan sampel antara 4 tahun sampai 35 tahun . Nilai rata-rata umur perusahaan sebesar 16,036 tahun dengan standar deviasi sebesar 7,720

Ketepatan waktu memiliki nilai nilai minimum 0 dengan nilai maksimum 1.

Hal ini menunjukkan bahwa tingkat ketepatan waktu yang dimiliki perusahaan sampel antara 0 hari sampai 1 hari sendangkan nilai rata-rata sebesar 0,50 dan standar deviasi 0,509 . Hal ini berarti $50 \%$ dari seluruh perusahaan sub sektor bank tepat waktu dalam penyampaian pelaporan keuangan.

Tabel 2.

Hosmer and Lemeshow Test

\begin{tabular}{ccccc}
\multicolumn{5}{c}{ Hosmer and Lemeshow Test } \\
\hline $\begin{array}{c}\text { Chi- } \\
\text { square }\end{array}$ & df & Sig. \\
\hline Step & 1 & 6,008 & 7 & 0,539 \\
\hline Sumber: & Data sekunder yang diolah, 2017
\end{tabular}


Kelayakan model regresi dinilai dengan hosmer and lemeshow test pada tabel 4.3 ditunjukkan bahwa nilai goodness of fit sebesar 6,008 dengan probabilitas sig. 0,539 dimana 0,539>0,05 Hal ini berarti model regresi yang digunakan dalam penelitian ini layak digunakan untuk analisis selanjutnya, karena tidak ada perbedaan antara model dengan nilai observasi.

\section{Tabel 3.}

\section{Model Summary}

\begin{tabular}{cccc}
\hline & \multicolumn{3}{c}{ Cox \& } \\
Step & $\begin{array}{c}\mathbf{2} \text { Log } \\
\text { likelihood }\end{array}$ & $\begin{array}{c}\text { Snell R } \\
\text { Square }\end{array}$ & $\begin{array}{c}\text { Nagelkerke } \\
\text { R Square }\end{array}$ \\
\hline 1 & $30,764^{\text {a }}$ & 0,25 & 0,333 \\
\hline \multicolumn{3}{c}{ Sumber: } & Data sekunder yang diolah, 2017
\end{tabular}

Nagelkerke $R$ Square digunakan untuk menjelaskan seberapa besar variabel dependen dapat dijelaskan oleh variabel independen. Pada tabel 4.4 diperoleh nilai Cox and Snell R Square sebesar 0,250 (25\%) dan Nagelkerke R Square sebesar 0,333 $(33,3 \%)$ yang berarti variabel dependen dapat dijelaskan oleh variabel independen sebesar 33,3\%, sedangkan sisanya dipengaruhi oleh variabel diluar penelitian $66,7 \%$

\section{Tabel 4}

\section{Variables in the Equation}

\begin{tabular}{llrrrrrrr}
\hline & \multicolumn{1}{c}{ B } & \multicolumn{1}{c}{ S.E. } & Wald & df & \multicolumn{1}{c}{ Sig. } & \multicolumn{1}{c}{$\operatorname{Exp(B)}$} \\
\hline Step 1 $^{\text {a }}$ & ROA & $-11,333$ & 33,873 & 0,112 & 1 & 0,738 & 0 \\
& SIZE & 1,049 & 0,646 & 2,634 & 1 & 0,005 & 5,35 \\
& STRUKTUR & & & & & & \\
& & 7,509 & 8,038 & 0,873 & 1 & 0,028 & 17,045 \\
& LAVERAGE & & & & & & \\
& & 3,149 & 2,62 & 1,445 & 1 & 0,229 & 23,317 \\
& AGE & 0,092 & 0,074 & 1,572 & 1 & 0,001 & 3,029 \\
& Constant & 2,6 & 9,668 & 0,072 & 1 & 0,788 & 13,459 \\
\hline
\end{tabular}


Variabel profitabilitas memiliki nilai koefisien negatif sebesar -11,333 dengan probabilitas signifikan sebesar 0,738>0,05 hal ini berarti bahwa $\mathrm{H}_{1}$ ditolak, dengan demikian profitabilitas tidak berpengaruh pada ketepatan waktu pelaporan keuangan. Variabel ukuran perusahaan memiliki nilai koefisien positif sebesar 1,049 dengan probabilitas signifikan sebesar 0,005 $<0,05$ hal ini berarti bahwa $\mathrm{H}_{2}$ diterima, dengan demikian terbukti bahwa ukuran perusahaan berpengaruh pada ketepatan waktu pelaporan keuangan.

Variabel struktur kepemilikan memiliki nilai koefisien positif sebesar 7,509 dengan probabilitas signifikan sebesar 0,028 $<0,05$ hal ini berarti bahwa $\mathrm{H}_{3}$ diterima, dengan demikian terbukti bahwa struktur kepemilikan berpengaruh pada ketepatan waktu pelaporan keuangan. Variabel leverage memiliki nilai koefisien positif sebesar 3,149 dengan probabilitas signifikan sebesar 0,229 > 0,05, hal ini berarti bahwa $\mathrm{H}_{4}$ ditolak, dengan demikian leverage tidak berpengaruh pada ketepatan waktu pelaporan keuangan. Variabel umur perusahaan memiliki nilai koefisien positif sebesar 0,092 dengan probabilitas signifikan sebesar 0,001 $<0,05$ hal ini berarti bahwa $\mathrm{H}_{5}$ diterima, dengan demikian terbukti bahwa umur perusahaan berpengaruh pada ketepatan waktu pelaporan keuangan.

Hipotesis menyebutkan jika profitabilitas berpengaruh positif pada ketepatan waktu pelaporan keuangan, namun berdasarkan hasil pengujian dalam penelitian ini menunjukkan bahwa profitabilitas tidak berpengaruh signifikan terhadap ketepatan waktu pelaporan keuangan suatu perusahaan. Profitabilitas tidak dapat memberikan 
ISSN: 2302-8556

E-Jurnal Akuntansi Universitas Udayana

Vol.22.1. Januari (2018): 572-594

pengukuran yang memadai atas efektivitas keseluruhan perusahaan dan profitabilitas tidak dapat mempengaruhi perusahaan untuk mempublikasikan laporan keuangannya secara tepat waktu. Hasil ini didukung oleh teori keagenan yang mengharuskan agen memberikan informasi secara terperinci kepada prinsipal walaupun informasi yang diberikan akan merugikan agen namun sudah menjadi kewajiban bagi agen untuk memberikan informasi yang dibutuhkan oleh prinsipal tanpa mengurangi keakuratan dari laporan keuangan tersebut. Hal ini konsisten dengan penelitian Budiyanto, Elma dan Dewi Utami (2015), yang menyatakan profitabilitas tidak berpengaruh pada ketepatan waktu pelaporan keuangan dan bukan merupakan satu-satunya tolok ukur untuk mempengaruhi ketepatan waktu laporan keuangan.

Hipotesis menyebutkan jika ukuran perusahaan berpengaruh positif pada ketepatan waktu pelaporan keuangan. Hasil penelitian menunjukan ukuran perusahaan berpengaruh pada ketepatan waktu pelaporan keuangan didasarkan pada teori keagenan yang menunjukan bahwa semakin besar suatu perusahaan maka hubungan antara manajemen dan investor semakin besar sehingga informasi mengenai laporan keuangan sangat dibutuhkan oleh investor, perusahaan besar mempunyai tingkat pertumbuhan penjualan yang tinggi sehingga perusahaan tersebut akan lebih berani untuk mengeluarkan saham baru. Ukuran perusahaan menunjukkan jumlah pengalaman dan kemampuan tumbuhnya suatu perusahaan yang mengindikasikan kemampuan dan tingkat risiko dalam mengelola investasi yang diberikan para stockholder untuk meningkatkan kemakmuran mereka. Hasil penelitian ini didukung 
oleh Beladina dan Marta (2015), Muhamad Riyadi (2016) yang menyatakan semakin besar suatu perusahaan maka perusahaan tersebut akan tepat waktu dalam menyampaikan pelaporan keuangan karena informasi mengenai laporan keuangan dapat membantu investor dalam pengambilan keputusan.

Hipotesis menyebutkan jika struktur kepemilikan berpengaruh positif pada ketepatan waktu pelaporan keuangan. Hasil pengujian hipotesis menunjukkan bahwa struktur kepemilikan berpengaruh signifikan terhadap ketepatan waktu pelaporan keuangan. Hasil penelitian ini didukung oleh teori keagenan dimana perusahaan dengan proporsi kepemilikan publik (pihak prinsipal) yang besar akan membutuhkan informasi mengenai laporan keuangan yang disampaikan oleh agen dan informasi tersebut akan dinilai oleh masyarakat secara luas tentang kinerjanya melalui laporan keuangan yang dipublikasikan. Perusahaan yang go public tentu lebih mementingkan tanggapan dan kritikan dari masyarakat dan masyarakat mampu mengambil keputusan bisnis untuk menanamkan sahamnya atau tidak diperusahaan tersebut. Perusahaan tentunya akan tepat waktu dalam melaporkan laporan keuangannya karena tidak mau dinilai buruk oleh masyarakat dan dengan tepat waktu tentu perusahaan akan lebih diuntungkan karena masyarakat akan lebih cepat mengambil keputusan bisnis. Hasil penelitian ini sesuai dengan penelitian yang dilakukan oleh Perdana Tulus (2014) dan Dewi Utami (2015) menyebutkan bahwa struktur kepemilikan berpengaruh secara signifikan terhadap ketepatan waktu pelaporan keuangan. 
ISSN: 2302-8556

E-Jurnal Akuntansi Universitas Udayana

Vol.22.1. Januari (2018): 572-594

Hipotesis menyebutkan jika leverage berpengaruh negatif pada ketepatan waktu pelaporan keuangan. Namun, Hasil pengujian hipotesis menunjukan leverage tidak berpengaruh terhadap ketepatan waktu pelaporan keuangan. Penelitian ini didukung dengan teori keagenan yang mengemukakan bahwa perusahaan atau agen yang memiliki kerjasama dengan pihak prinsipal dengan tingkat leverage yang semakin tinggi merupakan pertanda semakin besar pula penggunaan utang oleh agen yang akan membahayakan perusahaan. Namun, melihat kondisi perekonomian saat ini yang berhubungan dengan masalah hutang dianggap biasa dan bukan masalah yang luar biasa bagi sebuah perusahaan selama masih ada kemungkinan penyelesaiannya, sehingga informasi tentang hutang diabaikan oleh perusahaan.

Hasil penelitian ini konsisten dengan penelitian Syahresi Sukarman (2015) dan Muhamad Riyadi (2016) yang menyatakan leverage tidak berpengaruh terhadap ketepatan waktu pelaporan keuangan karena leverage tidak dapat menjadi pedoman dalam menentukan luas pengungkapan wajib laporan keuangan hal ini disebabkan adanya perbedaan kebijakan dari masing-masing perusahaan.

Hipotesis menyebutkan jika umur perusahaan berpengaruh positif pada ketepatan waktu pelaporan keuangan. Hasil dari penelitian mengungkapkan umur perusahaan berpengaruh pada ketepatan waktu pelaporan keuangan. Umur perusahaan merupakan salah satu faktor penentu dalam penentuan ketepatan waktu pelaporan keuangan suatu perusahaan merupakan indikator yang dapat mencerminkan tingkat pengalaman perusahaan dalam menjalankan bisnis dan seberapa mampu perusahaan dapat bertahan ditengah persaingan bisnis yang semakin ketat. Penelitian ini didasarkan oleh teori 
keagenan yang menjelaskan hubungan antara agen dengan prinsipal. Ketika sebuah perusahaan berkembang, pihak agen akan menjalin hubungan kerjasama dengan pihak prinsipal secara luas dan perusahaan belajar lebih banyak masalah pertumbuhan, penundaan yang luar biasa dapat diminimalisasikan. Akibatnya perusahaan mapan yang memiliki umur lebih tua cenderung lebih terampil dalam pengumpulan, pemrosesan dan menghasilkan informasi ketika diperlukan karena pengalaman belajar. Penelitian ini didukung oleh Iyoha (2012) dan Beladina (2015) menyatakan bahwa umur perusahaan mempengaruhi ketepatan waktu pelaporan keuangan perusahaan karena umur perusahaan sangat mempengaruhi keterampilan perusahaan dalam menyusun laporan keuangan secara baik mengingat umur perusahaan sudah matang dan memiliki banyak pengalaman dibidang bisnis.

\section{SIMPULAN}

Berdasarkan hasil analisis dan pembahasan bab-bab sebelumnya dapat disimpulkan bahwa Profitabilitas tidak berpengaruh terhadap ketepatan waktu pelaporan keuangan perusahaan. Hal ini disebabkan profitabilitas tidak dapat memberikan pengukuran yang memadai atas efektivitas keseluruhan perusahaan dan bukan merupakan satusatunya tolok ukur untuk mempengaruhi ketepatan waktu laporan keuangan. Ukuran perusahaan berpengaruh positif terhadap ketepatan waktu pelaporan keuangan perusahaan. Hal ini berarti semakin besar suatu perusahaan maka hubungan antara manajemen dan investor semakin besar sehingga perusahaan akan tepat waktu dalam menyampaikan pelaporan keuangan. Struktur Kepemilikan berpengaruh berpengaruh positif terhadap ketepatan waktu pelaporan keuangan perusahaan Hal ini menunjukan 
ISSN: 2302-8556

E-Jurnal Akuntansi Universitas Udayana

Vol.22.1. Januari (2018): 572-594

perusahaan dengan proporsi kepemilikan publik yang besar cenderung tepat waktu dalam pelaporan keuangan. Karena perusahaan akan nilai oleh masyarakat secara luas tentang kinerjanya melalui laporan keuangan yang dipublikasikan. Leverage tidak berpengaruh positif terhadap ketepatan waktu pelaporan keuangan perusahaan. Hal ini disebabkan manajemen tidak menganggap DER yang tinggi sebagai berita buruk bagi perusahaan yang mengakibatkan penundaan dalam penyampaian laporan keuangan dan masalah hutang dianggap biasa dan bukan masalah yang luar biasa bagi sebuah perusahaan selama masih ada kemungkinan penyelesaiannya, sehingga informasi tentang hutang diabaikan oleh perusahaan.Umur perusahaan berpengaruh berpengaruh positif terhadap ketepatan waktu pelaporan keuangan. Hal ini berarti perusahaan mapan yang memiliki umur lebih tua cenderung lebih terampil dalam pengumpulan, pemrosesan dan menghasilkan informasi ketika diperlukan karena pengalaman belajar dan bisnis.

Berdasarkan hasil penelitian, analisis, serta kesimpulan, maka saran yang dapat diberikan adalah bagi manajemen perusahaan, dengan mempertimbangkan pengaruh profitabilitas, ukuran perusahaan, struktur kepemilikan, leverage dan umur perusahaan diharapkan tepat waktu dalam penyampaian laporan keuangan perusahaan untuk mengantisipasi terjadinya teguran atau sanksi dari Bapepam. Bagi penelitian selanjutnnya, yang ingin meneliti pada sektor perbankan lebih baik menggunakan rasio khusus keuangan bank untuk mengukur kinerja keuangan perusahaan. Memperluas ruang lingkup penelitian, tidak hanya pada perusahaan dibidang perbankan namun juga pada perusahaan yang bergerak di bidang sektor lain. Menambah variabel independen seperti 
kualitas auditor dan likuiditas yang dapat mempengaruhi ketepatan waktu pelaporan keuangan.

\section{REFERENSI}

Arens, A. A. Elder \& Beasley, M.S. 2014. Auditing and Assurance Services An Integrated Approach. Journal of Financial Economics. London. Pearson Education.

Bapepam. 2012. Surat Keputusan Ketua Bapepam Tentang. Nomor: 431/BL/2012. Kewajiban Penyampaian Laporan Keuangan Berkala.

Budiyanto, S. dan Elma, M. A. 2015. Faktor-Faktor yang Mempengaruhi Ketepatan Waktu Pelaporan Keuangan. Jurnal Bisnis dan Akuntansi, 10 (1), h: 77-87.

Beladina, Dwi. 2015. Faktor-Faktor Yang Mempengaruhi Ketepatan Waktu Pelaporan Keuangan Perusahaan. Skripsi. Fakultas Ekonomi, UNISSULA.

Bonson, Enrique and Borrero, Cinta. 2011. Analysis Of The Timeliness Of Financial statement Submitted By Companies Of The Spanish Continous Market. Journal of Economic \& Business Studies (REBS), 4 (2), pp: 63-86

Dewi, Utami. 2015. Faktor-faktor yang Mempengaruhi Ketepatan Waktu Pelaporan Keuangan pada Perusahaan Sub Sektor Bank yang Terdaftar di Bursa Efek Indonesia. Skripsi. Universitas PGRI, Yogyakarta

Ghozali, Imam. 2013. Aplikasi Analisis Multivariate Dengan Program IBM SPSS 19. Semarang: Badan Penerbit Universitas Diponegoro, h: 139-163.

Iyoha, F.O. 2012. Company Attributes and the Timeliness of Financial Reporting in Nigeria. Journal of Financial Reporting. Covenant University. Pp: 41-49.

Jusia dan Dewi, Sofia Prima. 2013. Faktor-Faktor yang Mempengaruhi Ketepatan Waktu Penyampaian Laporan Keuangan pada Perusahaan Real Estate dan Property yang Terdaftar di BEI. Jurnal Akuntansi. 17 (3). h: 368-384.

Kartikasari, Lisa. dan Ifada, Luluk. M. 2010. Analisis Ketepatan Waktu Penyampaian Laporan Keuangan Perusahaan Go Publik di Pasar Modal: Bukti Empiris Dari Bursa Efek Indonesia.11 h:43-54. 
Kholisah, N. 2013. Pengaruh Penerapan IFRS, Ukuran Perusahaan, Profitabilitas, dan Kompleksitas terhadap Audit Delay (Studi Empiris pada Perusahaan Manufaktur tahun 2008-2011). Skripsi. Jakarta: UIN Syarif Hidayatullah Jakarta.

Marta, Sanjaya. 2015. Faktor-Faktor Yang Mempengaruhi Ketepatan Waktu Pelaporan Keuangan pada Perusahaan Manufaktur Di Bursa Efek Indonesia Tahun 2011-2013. Skripsi. Universias Udayana, Denpasar.

Marthani, D.T. 2013. Faktor-Faktor yang Mempengaruhi Ketepatan Waktu Penyampaian Laporan Keuangan (Studi Empiris pada Perusahaan Manufaktur yang Terdaftar di Bursa Efek Indonesia Tahun 2010-2012). Jurnal Ilmiah Mahasiswa FEB. 2 (1).

Muhammad, Riyadhi S. 2016. Analisis Faktor-faktor yang Mempengaruhi Ketepatan Waktu Pelaporan Keuangan ke Publik pada Perusahaan Poperty dan Real Estate yang Terdaftar di BEI. Skripsi. Universitas Lampung.

McGee, Robert W. 2007. Corporate Governance and The Timeliness of Corporate Financial Reporting: A Case Study of The Russian Energy Sector. Journal of Financial Reporting. Barry University USA.

Perdana, Tulus. 2014. Faktor-Faktor Yang Mempengaruhi Ketepatan Waktu Penyampaian Laporan Keuangan Pada Perusahaan Manufaktur Yang Terdaftar Di BEI Tahun 2008-2010. Skripsi. Universitas Muhammadiyah Surakarta.

Sugiyono. 2009. Metode Penelitian Bisnis Pendekatan Kuantitatif, Kualitatif, dan R\&D. Bandung: Alfabeta.

Syahresi, Sukarman. 2015. Faktor-faktor yang Mempengaruhi Ketepatan Waktu Pelaporan Keuangan pada Saham Syariah. Skripsi. UIN Syarif Hidayatullah

Wirda Fatkhiya. 2007. Faktor-faktor yang Mempengaruhi Tindakan Perataan Laba (Income Smoothing) pada Perusahaan Publik yang Terdaftar di BEJ. Skripsi. FEUNNES.

Weston, J. Fred. dan Thomas E. Copeland. 1995. Manajemen Keuangan. Jakarta: Gelora Aksara Pratama. 8 (1). h:238. 